\title{
Bacillus kochii sp. nov., isolated from foods and a pharmaceuticals manufacturing site
}

\author{
Correspondence \\ Herbert Seiler \\ herbert.seiler@wzw.tum.de
}

\author{
Herbert Seiler, ${ }^{1}$ Verena Schmidt, ${ }^{1}$ Mareike Wenning ${ }^{1}$ \\ and Siegfried Scherer ${ }^{1,2}$
${ }^{1}$ Department of Microbiology (ZIEL), Technische Universität München, Weihenstephaner Berg 3 , D-85350 Freising, Germany D-85350 Freising, Germany \\ ${ }^{2}$ Lehrstuhl für Mikrobielle Ökologie, Technische Universität München, Weihenstephaner Berg 3,
}

\begin{abstract}
Three Gram-staining-positive, strictly aerobic, motile, catalase-positive, endospore-forming rods, designated WCC $4582^{\top}$, WCC 4581 and WCC 4583, were isolated from two different food sources and a pharmaceuticals production site. The three isolates were highly similar in their $16 \mathrm{~S}$ rRNA gene sequences (100\% similarity) and groEL sequences (99.2-100\% similarity), Fouriertransform infrared spectroscopic fingerprints and other features tested. The isolates were most closely related to Bacillus horneckiae; the isolates and the type strain of $B$. horneckiae shared $97.6 \%$ and $89.6 \% 16 \mathrm{~S}$ rRNA gene and groEL sequence similarities, respectively. The organisms grew optimally at $30{ }^{\circ} \mathrm{C}$, at $\mathrm{pH} 7$ and in the presence of $0.5 \%(\mathrm{w} / \mathrm{v}) \mathrm{NaCl}$. The cell-wall peptidoglycan of WCC $4582^{\top}$ contained meso-diaminopimelic acid (A1 $\gamma$ ) and the genomic DNA $\mathrm{G}+\mathrm{C}$ content was 36.4 mol\%. DNA-DNA relatedness between strain WCC $4582^{\top}$ and $B$. horneckiae NRRL B-59162 ${ }^{\top}$ was $17 \%$. The three isolates are considered to represent a novel species of the genus Bacillus, for which the name Bacillus kochii sp. nov. is proposed. The type strain is WCC $4582^{\top}\left(=\right.$ DSM $23667^{\top}=$ CCUG $59877^{\top}=$ LMG $\left.25855^{\top}\right)$.
\end{abstract}

Microbial spoilage in food and contamination of pharmaceutical preparations pose a health risk to consumers and cause considerable economic losses in the industry. In particular, spore-forming bacteria are of importance, as they are heat resistant in food and endure desiccation and treatment with inorganic disinfectants, organic solvents and UV light in clean rooms. Formerly, the identification of spoilage micro-organisms was very costly and burdensome. Several research projects, therefore, developed an identification technology based on Fourier-transform infrared (FT-IR) spectroscopy, which fulfilled the following criteria: ease of use, fast and reliable results, high sample throughput and low costs as no consumables are required. During the course of many studies in our laboratory, thousands of micro-organisms have been isolated from industrial environments and identified by this method and novel species have been discovered (Bleicher et al., 2010; Rieser et al., 2012; Schmidt et al., 2009, 2012).

Strains WCC $4582^{\mathrm{T}}$ and WCC 4583 were isolated from products of two dairies in south Germany and strain WCC

Abbreviation: FT-IR, Fourier-transform infrared.

The GenBank/EMBL/DDBJ accession numbers for the 16S rRNA gene sequences of strains WCC $4582^{\top}$, WCC 4581 and WCC 4583 are FN995265, FR845720 and FR845721, respectively.

Three supplementary figures are available with the online version of this paper.
4581 was isolated from a clean room in a pharmaceuticals manufacturing site in north Germany. Isolation from the dairy products was carried out using tryptone soy agar (TSA; Roth) supplemented with $0.1 \%$ glucose (TSGA) or tryptone soy broth (TSB; Roth) solidified with $15 \mathrm{~g}$ agar $1^{-1}$ (TSBA); isolation from pharmaceutical clean room samples was carried out using TSA. For identification purposes, the FT-IR spectra of endospore-forming isolates were recorded as described by Kümmerle et al. (1998), Oberreuter et al. (2002) and Wenning et al. (2008) using an IFS-28B spectrometer and OPUS version 5.5 (Bruker Optics). The sample spectra were compared with a reference database for aerobic, mesophilic, spore-forming bacteria, including 770 spectra from 108 species and 12 genera. The three isolates described here displayed highly similar spectra but did not match any reference spectrum. The isolates were maintained as glycerol suspensions at $-80{ }^{\circ} \mathrm{C}$ and as Weihenstephan culture collection (WCC) lyophilized cells.

Almost-complete 16S rRNA gene sequences of the isolates (each $1511 \mathrm{bp}$ ) were obtained according to Schmidt et al. (2009). The identification of phylogenetic neighbours was initially performed using BLAST, MEGABLAST and FASTA (Altschul et al., 1997; Pearson \& Lipman, 1988; Zhang et al., 2000). Searches of public databases indicated that members of a presumably hitherto-unknown species of the 
genus Bacillus had been isolated. Only Bacillus horneckiae 1P01SC ${ }^{\mathrm{T}}$ (Vaishampayan et al., 2010) and non-type strains of Bacillus flexus, 'Bacillus granadensis', 'Bacillus pichinotyi' and Bacillus bataviensis exhibited $>97 \% 16 \mathrm{~S}$ rRNA gene sequence similarity. Additionally, sequences of 58 type strains with the highest sequence similarity scores were selected for the calculation of pairwise sequence similarity using the global alignment algorithm, which was implemented at the EzTaxon server (Chun et al., 2007). This comparison (Fig. S1, available in IJSEM Online) revealed that strains WCC $4582^{\mathrm{T}}$, WCC 4581 and WCC 4583 formed a distinct cluster ( $100 \% 16 \mathrm{~S}$ rRNA gene sequence similarity) within the genus Bacillus and were most closely related to B. horneckiae $1 \mathrm{P}^{2} 1 \mathrm{SC}^{\mathrm{T}}$ ( $97.6 \%$ sequence similarity). The type strains of Bacillus acidicola, B. pocheonensis, B. firmus, B. bataviensis, B. flexus, B. marisflavi, B. simplex, B. frigoritolerans, B. niacini, B. nealsonii, B. drentensis, B. shackletonii and $B$. circulans were more distantly related $(<96.8 \%$ sequence similarity). Phylogenetic and molecular evolutionary analyses were also conducted using MEGA (Tamura et al., 2007), Clustal X (Thompson et al., 1997), TREECON (Van de Peer \& De Wachter, 1997) and PhyloWin (Gouy et al., 2010). The topologies of trees calculated using neighbourjoining, maximum-parsimony and maximum-likelihood were basically all the same. Fig. 1 shows the position of the isolates among their nearest phylogenetic neighbours.

Partial groEL sequencing (530 bp) was performed in a $50 \mu \mathrm{l}$ reaction mix containing $1 \mathrm{U}$ Thermo-Start Taq DNA polymerase, $5 \mu \mathrm{l}$ Thermo-Start PCR buffer, $1.5 \mathrm{mM} \mathrm{MgCl}$, $200 \mu \mathrm{M}$ each dNTP (all Thermo Scientific), $0.5 \mu \mathrm{M}$ primer $\mathrm{H} 279,0.5 \mu \mathrm{M}$ primer $\mathrm{H} 280$ (Goh et al., 1996) and $1 \mu$ lysate. Cycling conditions comprised an initial denaturation at $95{ }^{\circ} \mathrm{C}$ for $15 \mathrm{~min}, 35$ cycles of denaturation at $95{ }^{\circ} \mathrm{C}$ for $20 \mathrm{~s}$, annealing at $40{ }^{\circ} \mathrm{C}$ for $45 \mathrm{~s}$ and extension at $72{ }^{\circ} \mathrm{C}$ for $1 \mathrm{~min}$ and a final extension step at $72{ }^{\circ} \mathrm{C}$ for $10 \mathrm{~min}$. Pairwise comparison of the groEL sequences confirmed that the three isolates were highly similar (99.2-100\% sequence similarity) and that B. horneckiae NRRL B-59162 ${ }^{\mathrm{T}}$ was the most closely related type strain (89.6\% groEL sequence similarity each). The neighbour-joining phylogenetic tree is shown in Fig. 2.

To further investigate the relationship between the isolates and their closest phylogenetic neighbour, a DNA-DNA reassociation study was performed by the DSMZ identification service (Braunschweig, Germany) based on spectroscopic hybridization. Bacterial cells grown in TSB (2 days, $30{ }^{\circ} \mathrm{C}$, shaking culture) were disrupted using a French pressure cell (Thermo Spectronic) and the DNA in the crude lysate was purified by chromatography on hydroxyapatite as described by Cashion et al. (1977). DNA-DNA hybridization was carried out as described by De Ley et al. (1970) under consideration of the modifications described by Huß et al. (1983) using a model Cary 100 Bio UV/VISspectrophotometer equipped with a Peltier-thermostatted $6 \times 6$ multicell changer and a temperature controller with an in situ temperature probe (Varian). DNA-DNA relatedness between strain WCC $4582^{\mathrm{T}}$ and B. horneckiae NRRL B$59162^{\mathrm{T}}$ was $17 \%$. This value is significantly below the $70 \%$ cut-off for the delineation of bacterial species suggested by Wayne et al. (1987).

Strains WCC $4582^{\mathrm{T}}$, WCC 4581 and WCC 4583 grew well on common media used for aerobic bacteria such as TSA, TSGA, TSBA, plate count agar (PCA; Merck) and PCA with powdered milk (PCMA; Roth) and in TSB aerated by shaking. The isolates produced ellipsoidal endospores in unswollen or sometimes only slightly swollen sporangia (Fig. S2, available in IJSEM Online). The biochemical and physiological characteristics of the isolates and the type strains of closely related species were determined (Logan et al., 2009). Conditions for growth were assessed in duplicate in TSB for up to 14 days; temperature for growth was also assessed on TSA. Growth at $\mathrm{pH} 4.0-11.0$ (at intervals of $0.5 \mathrm{pH}$ units), using $1 \mathrm{M} \mathrm{NaOH} / \mathrm{HCl}$ for $\mathrm{pH}$ adjustment and filtration for subsequent sterilization, and with $0-12 \%(\mathrm{w} / \mathrm{v}) \mathrm{NaCl}$ (at intervals of $1 \%$ ) were performed at $30{ }^{\circ} \mathrm{C}$. The temperatures determined for growth were $5,8,10,12,15,18,25,27,30,34,37,40,45,50$

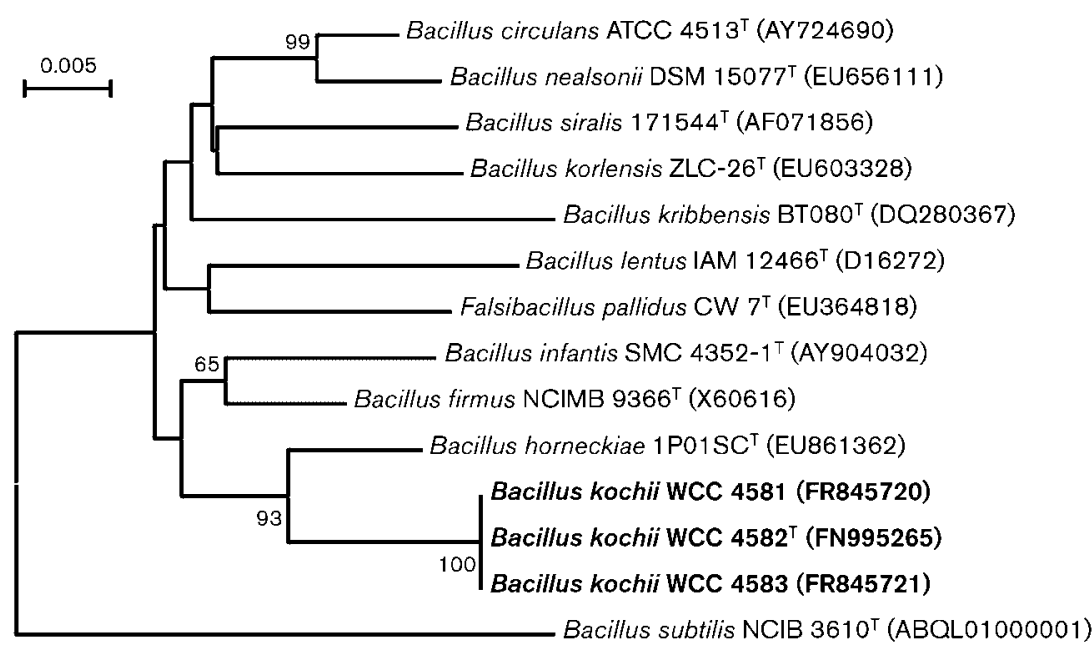

Fig. 1. Neighbour-joining tree based on nearly complete 16S rRNA gene sequences showing the phylogenetic positions of Bacillus kochii $\mathrm{sp}$. nov. and type strains of closely related species. Bootstrap values ( $>50 \%$ ) based on 1000 replications are shown at branch nodes. Bacillus subtilis NCIB $3610^{\top}$ was used as an outgroup. Bar, 0.005 substitutions per nucleotide position. 


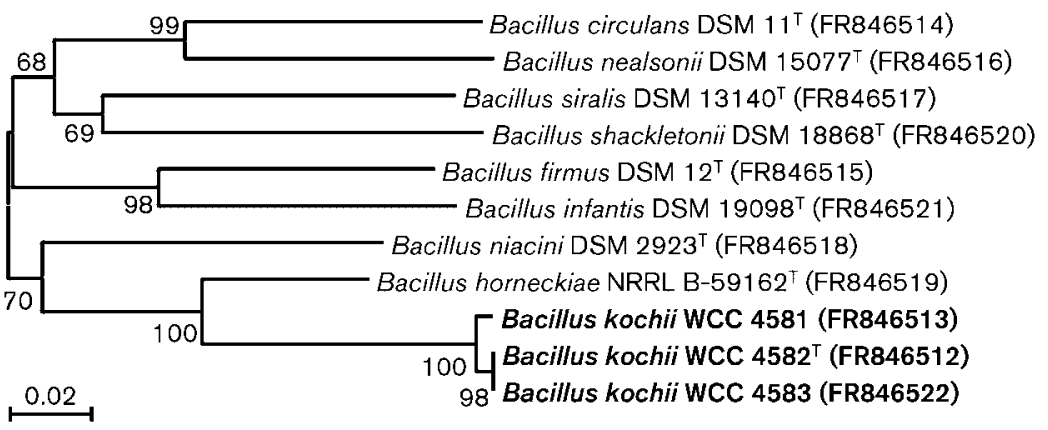

\begin{abstract}
Fig. 2. Neighbour-joining tree based on partial groEL sequences determined in this study showing the phylogenetic positions of Bacillus kochii sp. nov. and type strains of closely related Bacillus species. Bootstrap values (>50\%) based on 1000 replications are shown at branch nodes. Bar, 0.02 substitutions per nucleotide position.
\end{abstract}

and $55{ }^{\circ} \mathrm{C}$. Additionally, the isolates were characterized using the API $50 \mathrm{CH}$, API $20 \mathrm{NE}$, API Staph, API 20 E, API 20 Strep, API Coryne, ID 32 Staph, rapid ID 32 E, rapid ID 32 Strep, ID 32 GN and API ZYM systems (bioMérieux), according to the manufacturer's instructions except that the API $50 \mathrm{CH}$ wells were covered with paraffin, the strips were incubated for up to several days at $30^{\circ} \mathrm{C}$ in a humid chamber and API ZYM was analysed after $7 \mathrm{~h}$ at $30^{\circ} \mathrm{C}$. If different results were obtained from different systems, the API system was given priority over the ID system. Positive reactions were considered as positive after an incubation time according to the instructions of the supplier and as weakly positive after a prolonged incubation time. Resistance to lysozyme, anaerobic growth, hydrolysis of starch, production of dihydroxyacetone, reduction of nitrate, egg-yolk reaction and decomposition of casein, gelatin, xanthine, hypoxanthine and tyrosine were examined as described by Claus \& Berkeley (1986) and Logan \& De Vos (2009). Hydrolysis of Tweens 20, 40, 60 and 80 and tributyrin was determined as described by Harrigan \& McCance (1976). Columbia blood agar with sheep blood (Oxoid), DNase activity agar medium (Merck), ONPG ( $\beta$-galactosidase) strips (Oxoid) and Oxidase strips (Merck) were used as commercially available materials. The phenotypic characteristics are given in the species description and Table 1.

Analysis of the $\mathrm{G}+\mathrm{C}$ content of the genomic DNA, the examination of quinones, polar lipids and the peptidoglycan and the determination of the cellular fatty acid compositions were carried out by the DSMZ. For G $+\mathrm{C}$ content, bacterial cells were obtained and DNA was purified as described for the DNA-DNA reassociation study. DNA was hydrolysed with P1 nuclease and the nucleotides were dephosphorylated with bovine alkaline phosphatase (Mesbah et al., 1989). The resulting deoxyribonucleosides were analysed by HPLC (Tamaoka \& Komagata, 1984). DNA of strain WCC $4582^{\mathrm{T}}$ was hydrolysed twice and the two resulting hydrolysates were injected three times into the HPLC system, which resulted in six independent measurements. The $\mathrm{G}+\mathrm{C}$ content of strain WCC $4582^{\mathrm{T}}$ was $36.4 \pm 0.5 \mathrm{~mol} \%$. Cell mass for analysis of quinones and polar lipids was obtained from TSB shaken for 2 days at $30{ }^{\circ} \mathrm{C}$. Quinones were examined as specified by Altenburger et al. (1996). The menaquinones of strain WCC $4582^{\mathrm{T}}$ were MK-7 (97\%) and MK-6 (2\%), which is in line with phylogenetically related taxa. Polar lipids were examined as described by Tindall (1990a, b). Diphosphatidylglycerol, phosphatidylglycerol, phosphatidylethanolamine and aminophospholipid were the major polar lipids of strain WCC $4582^{\mathrm{T}}$. For cell-wall peptidoglycan and cellular fatty acid analysis, cell mass of strains was harvested from TSBA after cultivation for $24 \mathrm{~h}$ at $28^{\circ} \mathrm{C}$. The cell-wall peptidoglycan was isolated after disruption of the cells by shaking with glass beads and subsequent total hydrolysis $\left(4 \mathrm{M} \mathrm{HCl}, 100{ }^{\circ} \mathrm{C}, 16 \mathrm{~h}\right)$. The amino acids and peptides in the hydrolysate were analysed by two-dimensional ascending TLC on cellulose plates using previously described solvent systems (Rhuland et al., 1955; Schleifer, 1985). Strain WCC $4582^{\mathrm{T}}$ contained the cell-wall peptidodoglycan meso-diaminopimelic acid $(\mathrm{A} 1 \gamma)$. Fatty acids were extracted and analysed by GLC according to the instructions of the Microbial ID system (MIDI; TSBA 40 version 4.10; Verbarg et al., 2008). The major fatty acids of strains WCC $4582^{\mathrm{T}}$, WCC 4581 and WCC 4583 were iso$\mathrm{C}_{15: 0}(33-62 \%)$, anteiso- $\mathrm{C}_{15: 0}(11-25 \%)$, iso- $\mathrm{C}_{14: 0}$ (5$10 \%)$ and iso- $\mathrm{C}_{16: 0}(3-11 \%)$. Some of the reference strains exhibited a similar pattern of major fatty acids, as shown in detail in Table 2. An FT-IR-based dendrogram of the isolates and their closest phylogenetic neighbours was calculated (Fig. S3, available in IJSEM Online). The distances of repeated measurements of each strain demonstrated the spectral variance within and between the species tested. This cluster analysis confirmed the distinct position of the isolates that was observed with the 16S rRNA gene and groEL sequence analyses.

Three isolates found at different geographical locations are described in this paper: strain WCC $4582^{\mathrm{T}}$ from dairy A, strain WCC 4583 from dairy B and strain WCC 4581 from a pharmaceuticals production site. A variety of phenotypic characters (Table 1) were identical among the isolates. However, the isolates were not clonal, as demonstrated by the following differences: strain WCC 4581 and strain WCC 4583 had an identical 16S rRNA sequence whereas strain WCC $4582^{\mathrm{T}}$ differed at position 183 (according to Escherichia coli numbering) where it showed an $\mathrm{A} / \mathrm{T}$ polymorphism in the 16S rRNA operons. Strain WCC $4582^{\mathrm{T}}$ and strain WCC 4583 could not be differentiated on the basis of partial groEL sequences (Fig. 2) or FT-IR fingerprints (Fig. S3), but were clearly different in these 
Table 1. Characteristics that differentiate Bacillus kochii sp. nov. from type strains of closely related species

Taxa: 1, Bacillus kochii sp. nov. (WCC $4582^{\mathrm{T}}$, WCC 4581 and WCC 4583); 2, B. circulans DSM 11 ${ }^{\mathrm{T}}$; 3, B. firmus DSM 12 ${ }^{\mathrm{T}}$; 4, B. horneckiae NRRL B-59162 ${ }^{\mathrm{T}} ; 5$, B. infantis DSM $19098^{\mathrm{T}} ; 6$, B. nealsonii DSM $15077^{\mathrm{T}} ; 7$, B. siralis DSM $13140^{\mathrm{T}}$. All data were taken from this study unless otherwise indicated. + , Positive; $w$, weakly positive; - , negative; ND, no data available.

\begin{tabular}{|c|c|c|c|c|c|c|c|}
\hline Characteristic & 1 & 2 & 3 & 4 & 5 & 6 & 7 \\
\hline Cell length $(\mu \mathrm{m})$ & $3-13$ & $2-7$ & $1-5$ & $4-20$ & $3-10$ & $4-9$ & $2-5$ \\
\hline $\mathrm{pH}$ for growth & $6-10.5$ & $6-9.5$ & $6-10$ & $5.7-10.5$ & ND & $6-10$ & $6.5-10$ \\
\hline Hippurate hydrolysis (ID 32 Strep) & - & ND & ND & + & ND & ND & - \\
\hline \multicolumn{8}{|l|}{ Acid production from (API $50 \mathrm{CH}$ ): } \\
\hline Glycerol & + & + & + & - & + & + & + \\
\hline \multicolumn{8}{|l|}{ Growth on (ID 32 GN): } \\
\hline 2-Ketogluconate & - & + & - & + & - & + & + \\
\hline 3-Hydroxybenzoate & + & - & - & - & - & - & - \\
\hline Maltose & - & + & + & + & + & + & - \\
\hline Sucrose & - & + & + & + & + & + & - \\
\hline Lactate & - & + & + & + & + & - & + \\
\hline DNA G $+C$ content $(\mathrm{mol} \%)$ & $36.4 \pm 0.5^{*}$ & $35.7-36.2 \dagger$ & $40.7-41.4 \dagger$ & $35.6-36.1 \dagger$ & $40.8 \dagger$ & ND & $38.1 \pm 0.5$ \\
\hline
\end{tabular}

${ }^{\star}$ DNA G + C content was determined only for strain WCC $4582^{\mathrm{T}}$.

$\dagger$ Data taken from Logan \& De Vos (2009).

characters from strain WCC 4581. On the other hand, strain WCC 4581 and strain WCC 4583 were quite similar in their fatty acid compositions but different from strain WCC $4582^{\mathrm{T}}$ (Table 2).

While the three isolates and the type strain of $B$. horneckiae showed clear similarities, a considerable number of phenotypic and chemotaxonomic differences were observed. These, taken together with the results of $16 \mathrm{~S}$ rRNA gene and groEL sequence analyses, DNA-DNA relatedness and FT-IR typing, demonstrate that the isolates represent a novel species of the genus Bacillus, for which the name Bacillus kochii sp. nov. is proposed.

\section{Description of Bacillus kochii sp. nov.}

Bacillus kochii (ko.chi'i. N.L. gen. masc. n. kochii of Robert Koch, named in honour of the famous microbiologist with great merit in Bacillus anthracis research, to commemorate the centenary of his death on 27 May 1910).

Vegetative cells are motile rods $(0.5-0.8 \times 3-13 \mu \mathrm{m})$. Short chains are formed sporadically. Parasporal crystals are not produced. Ellipsoidal endospores lie paracentrally or subterminally and may slightly stretch sporangia sometimes. Colonies are cream, flat to low convex, spreading and translucent with irregular to filamentous margins. After $24 \mathrm{~h}$ on TSA at $30{ }^{\circ} \mathrm{C}$, colony diameter is $3-5 \mathrm{~mm}$; after $72 \mathrm{~h}, 15-20 \mathrm{~mm}$. An off odour is produced. Growth occurs at $10-40{ }^{\circ} \mathrm{C}$ (optimum $30{ }^{\circ} \mathrm{C}$ ), at $\mathrm{pH}$ 6.0-10.5 (optimum $\mathrm{pH} 7$ ) and with $0-10 \%(\mathrm{w} / \mathrm{v}) \mathrm{NaCl}$ (optimum $0.5 \% \mathrm{NaCl}$ ). Grows in the presence of $100 \mathrm{U}$ lysozyme $\mathrm{ml}^{-1}$, but not with $5 \mu \mathrm{g}$ novobiocin $\mathrm{ml}^{-1}$. Positive for Gram-staining, catalase and citrate utilization; negative for oxidase activity, anaerobic growth, Voges-Proskauer reaction and reduction of nitrate to nitrite. Does not produce dihydroxyacetone, gas from glucose, indole or hydrogen sulfide. Hydrolyses casein, DNA, gelatin and Tweens 20, 40, 60 and 80, but not aesculin, hippurate, lecithin, starch, tributyrin, tyrosine, urea, xanthine or hypoxanthine. On blood agar, $\beta$-haemolysis occurs. Weakly produces acid from glycerol and D-ribose; does not produce acid from $\alpha$ cyclodextrin, D-adonitol, amygdalin, D- or L-arabinose, Dor L-arabitol, arbutin, cellobiose, colistin, coumarate, dulcitol, erythritol, D-fructose, D- or L-fucose, D-galactose, gentiobiose, D-gluconate, D-glucose, D-glucuronate, glycerol, glycogen, inulin, itaconate, 2-keto-D-gluconate, 5-keto-D-gluconate, lactose, D-lyxose, maltose, D-mannitol, D-mannose, melezitose, melibiose, methyl $\alpha$-D-glucopyranoside, methyl $\alpha$-Dmannopyranoside, methyl $\beta$-D-xylopyranoside, myo-inositol, $N$-acetyl-D-glucosamine, palatinose, pullulan, raffinose, Lrhamnose, D-ribose, salicin, D-sorbitol, L-sorbose, starch, sucrose, D-tagatose, trehalose, turanose, xylitol or D- or Lxylose. As sole carbon sources for energy and growth, utilizes acetate, adipinate, L-alanine, citrate, D-gluconate, 3-hydroxybenzoate, 3-hydroxybutyrate, itaconate, malate, phenylacetate, L-proline, propionate, D-ribose, L-serine, suberate and valerate, but not L-arabinose, caprate, L-fucose, D-glucose, 
Table 2. Cellular fatty acid compositions of Bacillus kochii sp. nov. and the type strains of closely related species

Strains: 1, Bacillus kochii sp. nov. WCC $4582^{\mathrm{T}}$; 2, Bacillus kochii sp. nov. WCC 4581; 3, Bacillus kochii sp. nov. WCC 4583; 4, B. siralis DSM $13140^{\mathrm{T}} ; 5$, B. infantis DSM $19098^{\mathrm{T}}$; 6, B. horneckiae NRRL B$59162^{\mathrm{T}}$. Some rare trace derivatives were not given in the table. Data were taken from this study using cells harvested from TSBA after incubation for $24 \mathrm{~h}$ at $28{ }^{\circ} \mathrm{C}$.

\begin{tabular}{|lcccccc|}
\hline Fatty acid (\%) & $\mathbf{1}$ & $\mathbf{2}$ & $\mathbf{3}$ & $\mathbf{4}$ & $\mathbf{5}$ & $\mathbf{6}^{*}$ \\
\hline Straight chain & & & & & & \\
$\quad \mathrm{C}_{14: 0}$ & 1.0 & 0.9 & 1.2 & 3.2 & 2.4 & $0.9(1.1)$ \\
$\mathrm{C}_{15: 0}$ & - & - & - & 0.3 & - & - \\
$\mathrm{C}_{16: 0}$ & 0.8 & 0.5 & 0.6 & 5.8 & 1.8 & $0.5(0.5)$ \\
Branched & & & & & & \\
iso- $\mathrm{C}_{13: 0}$ & - & 0.2 & 0.2 & 0.2 & 0.2 & $0.2(0.2)$ \\
anteiso- $\mathrm{C}_{13: 0}$ & - & - & - & - & 0.1 & - \\
iso- $\mathrm{C}_{14: 0}$ & 10.1 & 5.9 & 5.3 & 3.3 & 1.1 & $4.3(4.0)$ \\
iso- $\mathrm{C}_{15: 0}$ & 33.4 & 62.1 & 59.5 & 46.0 & 44.5 & $57.4(54.3)$ \\
anteiso-C $15: 0$ & 25.4 & 10.7 & 14.1 & 19.0 & 31.5 & $14.2(19.9)$ \\
iso- $\mathrm{C}_{16: 0}$ & 10.7 & 3.4 & 2.8 & 3.0 & 1.6 & $3.3(2.5)$ \\
iso- $\mathrm{C}_{17: 0}$ & 1.2 & 1.2 & 1.4 & 3.0 & 1.8 & $1.9(1.3)$ \\
anteiso-C $\mathrm{C}_{17: 0}$ & 6.1 & 1.5 & 2.0 & 3.6 & 8.0 & $2.1(2.3)$ \\
iso- $\mathrm{C}_{17: 1} \omega 10 c$ & 0.5 & 2.4 & 2.2 & 2.3 & 1.1 & $2.1(2.3)$ \\
Unsaturated & & & & & & \\
$\mathrm{C}_{16: 1} \omega 7 c$ alcohol & 7.6 & 7.8 & 7.0 & 3.0 & 1.0 & $8.3(6.8)$ \\
$\mathrm{C}_{16: 1} \omega 11 c$ & 1.4 & 1.6 & 1.7 & 6.0 & 1.6 & $1.8(2.0)$ \\
Summed feature $4 \dagger$ & 1.8 & 1.8 & 2.1 & 1.2 & 2.8 & $2.8(2.9)$ \\
& & & & & & \\
\hline
\end{tabular}

${ }^{\star}$ Data in parentheses were taken from Vaishampayan et al. (2010) using cells harvested from TSA after incubation for $24 \mathrm{~h}$ at $32{ }^{\circ} \mathrm{C}$. $\dagger$ Summed features represent two or three fatty acids that cannot be separated by the Microbial Identification System. Summed feature 4 consisted of iso- $\mathrm{C}_{17: 1} \mathrm{I}$ and/or anteiso- $\mathrm{C}_{17: 1} \mathrm{~B}$.

glycogen, L-histidine, 4-hydroxybenzoate, 2-keto-D-gluconate, 5-keto-D-gluconate, lactate, malonate, maltose, Dmannitol, D-mannose, melibiose, myo-inositol, $\mathrm{N}$-acetyl-Dglucosamine, L-rhamnose, salicin, D-sorbitol or sucrose. With API, positive for alkaline phosphatase, glycyl-tryptophan arylamidase, leucine arylamidase, pyrazinamidase, pyroglutamate arylamidase and $\alpha$-chymotrypsin; weakly positive for acid phosphatase, cystine arylamidase, esterase (C4), esterase lipase (C8), leucine aminopeptidase, trypsin, tryptophan deaminase and valine arylamidase; negative for alanylphenylalanyl-proline arylamidase, arginine dihydrolase, $\alpha$ fucosidase, $\alpha$ - and $\beta$-galactosidase, $\alpha$ - and $\beta$-glucosidase, $\beta$-glucuronidase, indoxyl phosphatase, lipase (C14), lysine decarboxylase, $\alpha$ - and $\beta$-mannosidase, $N$-acetyl-D-glucosaminidase, naphthol-AS-BI-phosphohydrolase, ornithine decarboxylase, phenylalanine deaminase and tetrathionate reductase. The cell-wall peptidoglycan contains meso-diaminopimelic acid. The predominant menaquinone is MK-7. The major fatty acids are iso- $C_{15: 0}$, anteiso- $C_{15: 0}$, iso- $C_{14: 0}$ and iso- $\mathrm{C}_{16: 0}$. The major polar lipids are diphosphatidylglycerol, phosphatidylglycerol, phosphatidylethanolamine and aminophospholipid.
The type strain is WCC $4582^{\mathrm{T}}\left(=\mathrm{DSM} 23667^{\mathrm{T}}=\mathrm{CCUG}\right.$ $59877^{\mathrm{T}}=$ LMG $25855^{\mathrm{T}}$ ). Strain WCC $4582^{\mathrm{T}}$ and reference strain (WCC 4583) were isolated from different German dairy products. Another reference strain, WCC 4581 (=DSM 24673), was isolated from a pharmaceuticals production line in Germany. The DNA G $+\mathrm{C}$ content of the type strain is $36.4 \pm 0.5 \mathrm{~mol} \%$ (HPLC).

\section{Acknowledgements}

We thank J.L. Swezey (ARS Culture and Patent Culture Collection, Peoria, USA) for kindly providing B. horneckiae NRRL B-59162 ${ }^{\mathrm{T}}$.

\section{References}

Altenburger, P., Kämpfer, P., Makristathis, A., Lubitz, W. \& Busse, H.-J. (1996). Classification of bacteria isolated from a medieval wall painting. J Biotechnol 47, 39-52.

Altschul, S. F., Madden, T. L., Schäffer, A. A., Zhang, J., Zhang, Z., Miller, W. \& Lipman, D. J. (1997). Gapped BLAST and PSI-BLAST: a new generation of protein database search programs. Nucleic Acids Res 25, 3389-3402.

Bleicher, A., Neuhaus, K. \& Scherer, S. (2010). Vibrio casei sp. nov., isolated from the surfaces of two French red smear soft cheeses. Int $J$ Syst Evol Microbiol 60, 1745-1749.

Cashion, P., Holder-Franklin, M. A., McCully, J. \& Franklin, M. (1977). A rapid method for the base ratio determination of bacterial DNA. Anal Biochem 81, 461-466.

Chun, J., Lee, J.-H., Jung, Y., Kim, M., Kim, S., Kim, B. K. \& Lim, Y. W. (2007). EzTaxon: a web-based tool for the identification of prokaryotes based on 16S ribosomal RNA gene sequences. Int J Syst Evol Microbiol 57, 2259-2261.

Claus, D. \& Berkeley, R. C. W. (1986). Genus Bacillus Cohn 1872. In Bergey's Manual of Systematic Bacteriology, vol. 2, pp. 1105-1140. Edited by P. H. A. Sneath, N. S. Mair, M. E. Sharpe \& J. G. Holt. Baltimore: Williams \& Wilkins.

De Ley, J., Cattoir, H. \& Reynaerts, A. (1970). The quantitative measurement of DNA hybridization from renaturation rates. Eur J Biochem 12, 133-142.

Goh, S. H., Potter, S., Wood, J. O., Hemmingsen, S. M., Reynolds, R. P. \& Chow, A. W. (1996). HSP60 gene sequences as universal targets for microbial species identification: studies with coagulase-negative staphylococci. J Clin Microbiol 34, 818-823.

Gouy, M., Guindon, S. \& Gascuel, O. (2010). SeaView version 4: a multiplatform graphical user interface for sequence alignment and phylogenetic tree building. Mol Biol Evol 27, 221-224.

Harrigan, W. F. \& McCance, M. E. (1976). Laboratory Methods in Foods and Dairy Microbiology. London: Academic Press.

Huß, V. A. R., Festl, H. \& Schleifer, K. H. (1983). Studies on the spectrophotometric determination of DNA hybridization from renaturation rates. Syst Appl Microbiol 4, 184-192.

Kümmerle, M., Scherer, S. \& Seiler, H. (1998). Rapid and reliable identification of food-borne yeasts by Fourier-transform infrared spectroscopy. Appl Environ Microbiol 64, 2207-2214.

Logan, N. A. \& De Vos, P. (2009). Genus I. Bacillus. In Bergey's Manual of Systematic Bacteriology, vol. 3, pp. 21-128. Edited by P. De Vos, G. Garrity, D. Jones, N. R. Krieg, W. Ludwig, F. A. Rainey, K. H. Schleifer \& W. B. Whitman. New York: Springer.

Logan, N. A., Berge, O., Bishop, A. H., Busse, H.-J., De Vos, P., Fritze, D., Heyndrickx, M., Kämpfer, P., Rabinovitch, L. \& other authors. (2009). 
Proposed minimal standards for describing new taxa of aerobic, endospore-forming bacteria. Int J Syst Evol Microbiol 59, 2114-2121.

Mesbah, M., Premachandran, U. \& Whitman, W. B. (1989). Precise measurement of the $\mathrm{G}+\mathrm{C}$ content of deoxyribonucleic acid by highperformance liquid chromatography. Int J Syst Bacteriol 39, 159-167.

Oberreuter, H., Seiler, H. \& Scherer, S. (2002). Identification of coryneform bacteria and related taxa by Fourier-transform infrared (FT-IR) spectroscopy. Int J Syst Evol Microbiol 52, 91-100.

Pearson, W. R. \& Lipman, D. J. (1988). Improved tools for biological sequence comparison. Proc Natl Acad Sci U S A 85, 2444-2448.

Rhuland, L. E., Work, E., Denman, R. F. \& Hoare, D. S. (1955). The behaviour of the isomers of $\alpha, \varepsilon$-diaminopimelic acid on paper chromatograms. J Am Chem Soc 77, 4844-4846.

Rieser, G., Wenning, M. \& Scherer, S. (2012). Micrococcus cohnii sp. nov., isolated from air of a medical practice. Int J Syst Evol Microbiol (in press). doi: 10.1099/ijs.0.036434-0

Schleifer, K. H. (1985). Analysis of the chemical composition and primary structure of murein. Methods Microbiol 18, 123-156.

Schmidt, V. S., Mayr, R., Wenning, M., Glöckner, J., Busse, H.-J. \& Scherer, S. (2009). Bavariicoccus seileri gen. nov., sp. nov., isolated from the surface and smear water of German red smear soft cheese. Int J Syst Evol Microbiol 59, 2437-2443.

Schmidt, V. S., Wenning, M. \& Scherer, S. (2012). Sphingobacterium lactis sp. nov. and Sphingobacterium alimentarium sp. nov., isolated from raw milk and the dairy environment. Int J Syst Evol Microbiol (in press). doi: 10.1099/ijs.0.036327-0

Tamaoka, J. \& Komagata, K. (1984). Determination of DNA base composition by reversed-phase high-performance liquid chromatography. FEMS Microbiol Lett 25, 125-128.

Tamura, K., Dudley, J., Nei, M. \& Kumar, S. (2007). MEGA4: molecular evolutionary genetics analysis (MEGA) software version 4.0. Mol Biol Evol 24, 1596-1599.
Thompson, J. D., Gibson, T. J., Plewniak, F., Jeanmougin, F. \& Higgins, D. G. (1997). The CLUSTAL_X windows interface: flexible strategies for multiple sequence alignment aided by quality analysis tools. Nucleic Acids Res 25, 4876-4882.

Tindall, B. J. (1990a). Lipid composition of Halobacterium lacusprofundi. FEMS Microbiol Lett 66, 199-202.

Tindall, B. J. (1990b). A comparative study of the lipid composition of Halobacterium saccharovorum from various sources. Syst Appl Microbiol 13, 128-130.

Vaishampayan, P., Probst, A., Krishnamurthi, S., Ghosh, S., Osman, S., McDowall, A., Ruckmani, A., Mayilraj, S. \& Venkateswaran, K. (2010). Bacillus horneckiae sp. nov., isolated from a spacecraft-assembly clean room. Int J Syst Evol Microbiol 60, 1031-1037.

Van de Peer, Y. \& De Wachter, R. (1997). Construction of evolutionary distance trees with TREECON for Windows: accounting for variation in nucleotide substitution rate among sites. Comput Appl Biosci 13, 227-230.

Verbarg, S., Frühling, A., Cousin, S., Brambilla, E., Gronow, S., Lünsdorf, H. \& Stackebrandt, E. (2008). Biostraticola tofi gen. nov., spec. nov., a novel member of the family Enterobacteriaceae. Curr Microbiol 56, 603-608.

Wayne, L. G., Brenner, D. J., Colwell, R. R., Grimont, P. A. D., Kandler, O., Krichevsky, M. I., Moore, L. H., Moore, W. E. C., Murray, R. G. E. \& other authors. (1987). Report of the ad hoc committee on reconciliation of approaches to bacterial systematics. Int J Syst Bacteriol 37, 463-464.

Wenning, M., Scherer, S. \& Naumann, D. (2008). Infrared spectroscopy in the identification of microorganisms. In Vibrational Spectroscopy for Medical Diagnosis, pp. 71-96. Edited by M. Diem, P. R. Griffith \& J. M. Chalmers. Chichester: Wiley.

Zhang, Z., Schwartz, S., Wagner, L. \& Miller, W. (2000). A greedy algorithm for aligning DNA sequences. J Comput Biol 7, 203-214. 